\title{
Reality, Innovation And The Challenges Of Using Village Funds For Improving The Quality Of Life In The Community (Study in Some Villages On Kupang Regency)
}

\author{
Reyner F. Makatita ${ }^{1}$, Petrus E. de Rozari ${ }^{2}$ and Reni R. Masu ${ }^{3}$ \\ 1,2,3 Lecturer at the Faculty of Economics and Business and Faculty of Law, University of Nusa Cendana \\ ${ }^{* 1}$ angkymakatita01@gmail.com
}

\begin{abstract}
Purpose: The purpose of this study is to determine the reality, innovations and challenges of Using Village Funds in Improving Community Quality of Life (Case Studies in Several Villages in Kupang Regency).

Research Methodology: This research is included in qualitative descriptive research. The data collection techniques used were questionnaires, interviews and documentation studies.

Results: The results of this study indicate that several villages that are on the poverty line in Kupang Regency show that the readiness of village officials and village communities in utilizing and using village funds is still low.

Limitations: This research was only conducted in the village a survey of several villages located in the poverty line in Kupang Regency that is Oesao Village, Oebelo, Mata Air and East Baumata Village.

Contribution: The results of this study are expected to be material for consideration and evaluation in the use of village funds in improving the quality of life of the people on Kupang Regency.
\end{abstract}

Keywords:

Challenges, Innovation, Reality, Quality of Life, Village Fund

Article Received: 18 October 2020, Revised: 3 November 2020, Accepted: 24 December 2020

\section{Introduction}

The regional development of East Nusa Tenggara Province is temporarily being encouraged towards the welfare of the community and an increase in the quality of life. This is shown through the attention of the central government which is strengthened by the existence of village funds. Village funds began in 2015 until now in 2020 with the amount of village funds in 2019 of IDR 800 million. The absorption of this fund has been optimized through Ministerial Regulation No. 16 of 2018 which includes priorities for the use of village funds so as to minimize fraud. Paragraph 3 in article 4 states that the priority for the use of village funds is expected to provide the greatest possible benefit for the village community in the form of improving the quality of life, increasing welfare and poverty alleviation and improving public services at the village level.Since being rolled out in 2015 to 2019 , the total village funds flowing into the East Nusa Tenggara Province (NTT) amounted to IDR 10,592,633,206. Unfortunately, poverty in NTT remains a specter and a classic problem, (Manuk: Pos Kupang 20/5/2019). Further more Maritje Pattiwaelapia (Pos Kupang, 15/7/2019) presented data on the poor population in March 2019 of 1,146.32 thousand people, an increase of 12.21 thousand people in September 2018 and an increase of 4.15 thousand people compared to March 2018. On average, Poor households in NTT Province in March 2019 had 5.84 household members. Thus, the average poverty line per poor household is IDR 2,183,704 / poor household / month.

The results of the survey and data on priority locations for handling poverty and stunting 2020 (Bappeda NTT) in several villages located on the poverty line in Kupang Regency, consisting of the villages of Oesao, Oebelo, Mata Air and East Baumata. These four (4) villages show that the 
readiness of village officials and village communities in utilizing and using village funds is still low. This means that the village has not been able to manage large amounts of funds because it does not have human resources with adequate knowledge and expertise in transferring work programs that have been derived from the central government, to manage village finances, coordinate the implementation of village development and empower village communities.Oriented from this, the authors are interested in conducting research on the topic: Reality, Challenges and Innovations for Using Village Funds in Improving the Quality of Life of the Community (Case Studies in Several Villages in Kupang District).

Taking into account the problems that occurred in six villages in Kupang Regency, the researchers formulated several research problems as follows:

1. How is the reality, challenges in using village funds in improving the quality of life of the Community?

2. What innovations and strategies will be produced to overcome problems in the use of village funds?

3. Model for developing the use of village funds effectively and efficiently!

To answer some of the problems above, there are several objectives that must be achieved as follows:

1. Identify the realities and challenges that occur when the community before getting village funds and after obtaining village funds,

2. Analyzing innovations and strategies for using village funds

3. The model for developing the use of village funds effectively and efficiently in improving the quality of life of the community.

\section{Literature Review}

\subsection{State Of The Art}

State Of The Art in this research that the level of attainment of the quality of human life needs to pay attention and instill three conceptual approaches, namely: The first approach, which is closely developed with psychological research, is based on the idea of the subject of welfare, meaning that striving for humans to be 'happy' and 'satisfied' with their lives is a universal goal of human existence. The second approach is rooted in the idea of capability, which means a person's life as a combination of activities and self and freedom to choose between these functions. The foundation of this capabilities approach has strong roots in philosophical ideas about social justice, reflects a focus on human goals and respects the individual's ability to pursue and realize goals he believes in, and plays the role of ethical principles in designing a good society. The third approach, developed in the economics tradition, is based on the idea of a fair allocation.

This level of novelty opens the horizons of thinking and acting of village fund managers to create and produce village products that are valuable in the eyes of the community. The village is a representation of the smallest legal community unit that has existed and is growing. As a form of State recognition of villages, especially in order to clarify the functions and authorities of villages, and strengthen the position of villages and village communities as development subjects, it is necessary to have structuring and regulating policies regarding villages which were realized by the issuance of Law Number 6 of 2014 concerning Villages 10).The 2019 State Budget Financial Note states that in 2019, the allocation of village funds will be directed at supporting more inclusive and transparent development.

\subsection{Village Community Life}

Providing greater opportunities for villages to take care of their own governance as well as equitable development implementation is expected to increase prosperityrefers to social conditions, social needs are met and social opportunities are createdand the quality of life of rural communities, so that problems such as inequality between regions, poverty, and other socio-cultural problems can be minimized 2). Many obstacles are still found in the distribution and use of Village Funds, causing the desired Village Development to be not 
implemented, one of which is poverty 1). In the planning and budgeting stage, the village government must involve the village community as represented by the Village Consultative Body (BPD), so that the work programs and activities that are compiled can accommodate the interests and needs of the village community and match the capabilities of the village1). Village development needs to be enhanced by empowering the local economy, creating access to local transportation in growth areas, and accelerating the fulfillment of basic infrastructure ${ }^{3}$ ). To see the growth and development of the use of Village Funds, there are 4 variables that are the main highlights in the discussion of this research, namely:

\section{Reality of Society}

Village communities are always synonymous with people who lack information and communication about the development of modern technology and have very low knowledge, skills and skills. Fulfilling the needs for clothing, food and shelter is always limited due to the lack of road access and transportation. Another factor is that government agencies do not pay attention to the needs and interests of village communities. For this reason, the village government must be more focused and united with the community to be more independent in managing the government with various natural resources owned, including the management of finances and assets belonging to the village12). Examples of cases that occur today are that the performance of the distribution and use of Village Funds is still facing obstacles 2). The process that should be in distribution, is via State Public Cash Account (RKUN) to Regional General Cash Account (RKUD) or from RKUD to Village Cash Account (RKDes) but this did not happen. Or the process of using funds must be through village-owned enterprises (BUMDes).

2. Village Fund Innovations

Innovation in a broad definition can be defined as a process resulting from the development of the use of knowledge, skills and experience both individually and in groups to create or improve a product in the form of goods or services that can provide added value in the fields of infrastructure, human resources, economy and socio-cultural. Definition of village innovationis the process of developing knowledge, skills and experience gleaned from the results of the work of the villages in implementing existing or recent village development in the form of goods or services that can provide added value in a sustainable manner, either through infrastructure development, human resource management, the economy and socio-cultural. The objective of the village innovation program is to improve the quality of the use of village funds through various development activities and empowerment of village communities that are more innovative and sensitive to the needs of village communities.

3. Challenge

The powerlessness of human resources in managing village funds has an impact ondevelopment and empowerment of rural communities. For this reason, the village government is obliged to prepare planning and budgeting that involves the village community with great responsibility by applying the principle of accountability in its governance, where all the end of activities in the implementation of village governance must be accountable to the village community in accordance with the provisions.

4. Improved Quality of Life

Quality of life is a broader concept than economic production and living standards. The quality of life includes the full set of factors that affect what we value in this life, beyond its material side which consists of: health, education, personal activities, governance, social connections, and environmental conditions. Each individual has a different quality of life depending on each individual in addressing the problems that occur in him. If you face it positively, the quality of life will be good, but negatively, the quality of life will be bad and will have an impact on poverty. The causes of poverty related to the human 
condition itself are a lack of belief in one's abilities, a reluctance to actualize the existing potential in the form of serious real work, and an unwillingness to give optimal respect to the cycles of time. According to the dominancedependency theory that the causes of poverty and underdevelopment are not just factors that exist in the community concerned such as lack of capital, low education, population density, lack of nutrition and so on. More than that these factors are only attributes of poverty, however poverty itself is rooted in a history of exploitation, especially what is practiced penetrating foreign or international capitalist powers, dominsai and profit-making.

Literally poverty comes from the word poor, which means "no possessions". According to Koenrad in Sarosa (2006), exaggerating poverty will tend to forget what they (the poor) have. The poor are not "without" people. From an economic point of view, they are people who have "a little" and on the other hand they also have rich cultural and social capital. Experts say that countries or regions with high poverty levels are generally caught in a cycle of poverty. The poverty circle is a series of circular forces that interact with each other in such a way that it places a country / region that has a high poverty rate to remain in lagging control.

According to Sumodininggrat (2003), there are three strategies to empower the community, namely:

1) Creating an atmosphere or climate that allows the potential of the community to develop.

2) Strengthening the potential or power of the community.

3) Providing protection in the empowerment process must be prevented from becoming weaker.

In the context of poverty, society is not only approached as an object but must be viewed as a subject or actor grouped into lowincome groups of people.

\section{Research methodology}

\subsection{Research Design}

Epistemologically, in quantitative research, a paradigm is accepted that the main source of knowledge is facts that have occurred, and are captured by the senses and are in accordance with previous theories. Qualitative research is a humanistic research model, which places humans as the main subject in socio-cultural events. In Weber's view, human behavior is not necessarily a consequence of a number of views or doctrines that live in the heads of the perpetrators. Ontologically, social phenomena, culture and human behavior are not enough to record things that appear to be real, but must examine the whole in the totality of the context.

\subsection{Research Approach}

The research approach is considered the most appropriate because scientific research is basically an attempt to reveal natural phenomena in a systematic, controlled, empirical, and critical manner. If further translated into the language of statistics, the meaning of the research approach is an attempt to reveal the influence between variables. This study used an in-depth survey method (in dept interview). The research description contains descriptions but as a relational study the focus lies on explaining the relationships between variables.

\subsection{Data Collection Techniques}

The required data collection techniques (Sugiyono: 2013) consist of:

(1) Interview Techniques

(2) Questionnaire

\subsection{Variable Operationalization}

This study uses dependent variables, independent variable and variables mediation. The explanations for the variables in this study are as follows:

1. The independent variable (independent variable). Independent variables are variables that can influence or be a cause for other variables. In this study, the independent variables were reality, innovation and challenges in using village funds in improving 
the quality of life of the community with the instruments developed by Dwiyanto (2012);

2. Dependent variable. The dependent variable or dependent variable (Y) in this study is to improve the quality of life of the community.

\subsection{Population and Sample}

Population and sample are formed in the unit of analysis consisting of Village head, youth organization, PKK activator team, village community and the Village Consultative Body (BPD).For this reason, the type of probability sampling chosen is simple random sampling. The focus of research is on the community and village government who receive Village Fund by observingInnovation in the use of village funds in improving the quality of life of the community.

3.6 Data Analysis

The selected research locations were villages in Kupang Regency. Primary and secondary types of data are collected by means of data collection through questionnaires, interviews and documentation and through focus group discussions. The analysis tool was carried out by qualitative descriptions.

\section{Results and Discussions}

\subsection{The Reality Of The Society}

Society is formed because of a group of people who want to interact, interact and complement each other's needs. With the life of interacting and complementing each other, it opens the thinking horizons of certain groups to make new breakthroughs in facing the life of the world which is always advancing and developing. The village communities referred to in this research are the people of Oesao, Oebelo, Mata Air and East Baumata villages. Many problems faced by the community before the existence of village funds, namely lack of water, foodstuffs due to drought, many children affected by malnutrition and stunting, and unemployment.

However, in community life, there are limitations that can and cannot be entered by community groups because society consists of people who live in urban areas and rural communities. These limits consist of:
1. Structural factors

The social structure is a guideline for every community who is able to act as a partner or network of cooperation that functions to integrate the same characters in behavior. Urban communities have a more individual character meaning they work and fulfill their needs for the interests of themselves and their families, while rural communities are very complex in their lives because there are cultural, religious and ethnic demands that must be obeyed. Looking at this life, there are phenomena that make rural communities have a strong desire to urbanize to urban areas. The phenomenon is that in the city there are many jobs, not bound by rules or customs, culture and in the city it is also easy to meet the needs of the people every day. Human interaction with the environment is basically driven by the desire to fulfill basic human needs. All experiences that humans acquire as a result of their interaction with the environment are recorded in memory. Experiences that are good and beneficial will be practiced in life over and over again and are called habits. On the other hand, experiences that are unpleasant or detrimental are avoided, giving birth to the concept of taboo or known as pemali. The whole result of experience whether in the form of habits and abstinence is called knowledge. The systematic and repeated use of knowledge is called Science. Theoretically, meeting the main basic needs consists of::

a. Fulfillment of basic biological needs includes clothing, food, shelter, reproduction, health, and self-defense.

b. The fulfillment of social needs includes the need to live together to achieve common and individual goals, the formation of communities and social groups as well as various social orders.

c. Fulfilling integrative or psychological needs includes the need for ethics and morals, a sense of beauty and so on.

2. Individual Factors 
A human being who wants to live alone or individually is very good so as not to be affected by negative factors that occur today (fraud, theft, corruption, etc.). But when he is in an organizational group, the individual person must be formed into a person who has organizational behavior that can act and interact with other people. Must have the ability to be able to carry out several activities in one job and be able to exploit it through the resulting performance so that village productivity can be achieved. Knowledge is the result of human experience obtained from the process of interaction with the environment. According to Charles Erasmus, that every person has essentially 2 (two) important elements, namely motive and sensory power. Sensory power is active which is obtained repeatedly from past experiences. The combination of motives and senses will produce desires and desires that will become behavior. Changes in a person's experience will provide opportunities for changes in his desires. Thus, repeated past experiences are an important element of giving a cultural pattern in the form of ideas (ideas, behavior and behavioral results).

3. Economic Factors

The main purpose of human life is to meet personal and family needs. This goal will be achieved when he works. City communities work in government agencies, the private sector, Non Govermental Organization/NGOs (LSM), and Micro, Small and Medium Enterprises (UMKM). The villagers work in the fields as farmers, fishermen and manual laborers. There is a very basic difference when they are paid a wage. But let's see that rural communities are the backbone of urban society to meet their food and drink needs. The main source of livelihood for dry land communities in NTT is farming. In farming, there are 2 (two) sources of life, namely dry land farming and raising livestock. Apart from farming and raising livestock, people who live on the coast have a livelihood of fishing in the sea and looking for marine life that can be consumed (fish, shellfish, snails, crabs, and seaweed) in the sea along the coast during tombeting (low tide). The life of dry land farming is in the form of shifting cultivation, gardening (for tree crops or perennial crops) and utilization of yard land. There are 2 (two) types of land for cultivation, namely new fields, namely those that have just been opened by clearing shrubs and village forests then clearing by burning, and old fields, namely those that have been cultivated for several years. In cultivating cultivation, after the fields have been cultivated for several years, then they are not cultivated (bero) for several planting seasons because the soil fertility has decreased.

4. Availability of infrastructure factors

If it is associated with repeated past experiences, the East Nusa Tenggara (NTT) region is also related to the environmental conditions of dry land, choppy, hilly and mountainous topography as well as various recurring threats from the past that haunt the survival of the community. Thus, the environmental conditions of dry land which are characterized by drought, which carry the risk of crop failure, must always be taken into account by the people of NTT in their daily lives. This reality is experienced repeatedly and forms the senses as well as perceptions and mindsets of the community which in turn influence behavior, as part of the culture of the dry land communities with a dry climate.

\subsection{Community Innovation}

\section{"We cannot solve our problems with the same thinking we used when we created them." -Albert Einstein}

Community innovation as a special form of place-based social innovation, in the specific geography of the community. The goal of social innovation - the resolution of complex social and environmental challenges - and a journey - to design new approaches that engage all stakeholders, leveraging their competence and creativity to design new solutions. As a dynamic 'living laboratory', communities offer the perfect platform for innovation. Community change will occur through effective, innovative innovations 
that require an appreciation of the problem it is trying to solve, as well as a deep understanding of the unique characteristics of a community - its place and people. Every innovation has two parts: the first is the discovery of the object itself; the second is the preparation of expectations so that when the discovery arrives,

The results of the research through direct interviews with the village head and several communities involved proved that there were certain individuals or individuals who opposed the use of village funds for the benefit of the community and some were very sincere.

\subsection{Discussion}

Given that the role of humans in the organization is very important, it is necessary to have good cooperation in carrying out a village goal. No matter how good the plan is made by the manager, without the support of employees in carrying out the work, the goals to be achieved will not be achieved. An employee may or may not do the job assigned to him well. If the subordinates have carried out the duties assigned to him properly, this is what we want. But if the assigned task is not carried out properly, then we need to know the reasons. Maybe he is not able to complete the assigned job, but maybe he also does not have the drive (motivation) to work well. So that employees want to work hard and with high morale so as to increase village productivity, something is needed that can motivate employees, one of which is by paying attention to wages that are in accordance with the wishes of the employees. If the employees' wages are neglected by the Village, it will cause various problems for the Village, make employees lazy to work, carry out strikes, or maybe make efforts to move to other villages that better guarantee their welfare. On the other hand, if the village has wages and employee welfare that are well planned and well received by the employees, it is considered to be one of the factors that can motivate them to be able to increase employee productivity.

With this labor productivity is needed, because a person's productivity and skills develop through and in work. The low productivity and skills of a person, often caused by mistakes in placing in a job that is not finished with education and skills. This productivity problem is experienced by almost all large villages, as well as those classified as developing. In order for the resulting productivity to increase, the village can do it by providing a lot of wages and wages that motivate employees, and employee discipline must be improved. With an increase in productivity, of course, there will be great benefits such as the benefits obtained by the village. The background of this research problem is that increasing the productivity (innovation) of a village is one of the main goals. To achieve the success of this productivity increase, several factors are needed that can influence it. Due to time constraints, the authors here will only discuss the effect according to employee wages on employee work productivity. To be able to support the smooth running of products in the village, it is also necessary to have employees whose abilities are good and in accordance with the conditions of their work, so that they can carry out their work properly, because the abilities or skills possessed by an employee have a very strong influence on employee productivity.

The development of the quality of Human Resources is increasingly important. This is because villages that employ Human Resources, want good results and benefits and can keep up with changes and developments that occur in the Village. Motivation and work experience are things that play an important role in increasing work effectiveness. Because people who have high motivation and work experience will try their best so that their work can succeed as well as possible, will form an increase in work productivity. (Moekijat, 1999). Every village always wants the productivity of each employee to increase. To achieve this, the village must provide good motivation to all employees in order to achieve work performance and increase productivity. With the addition of a work experience that the employees have, it will provide a great relationship in the effort to achieve productivity levels. As for these efforts by providing several work facilities 
that are very supportive in increasing productivity to all employees.

These facilities include work clothes, guaranteed meals, recreation, places of worship, sports rooms, holiday allowances, treatment rooms, insurance, salaries, bonuses, overtime pay and so on. All of this is provided by the Village, so that all employees who work in it are truly guaranteed as well as can create a good motivation to achieve productivity levels. Education level and work experience also take precedence. Especially for the bookkeeping or office, at least it is limited to high school education. While the production department has a minimum junior high school education. However, in the employee recruitment process, the Village prioritizes prospective employees who already have work experience from similar villages.

In relation to the Village Fund provided by the Ministry for all villages in Indonesia, from the results of the above research the researchers relate it to the understanding, understanding and implementation of Village Funds in each Village. Village Fund Allocation (ADD) is part of the balance funds received by the regency/city. The amount is at least $10 \%$ of the balance fund after deducting the Special Allocation Fund.

\section{General Village Finance Arrangements}

All village rights and obligations that can be valued in money as well as everything in the form of money and goods related to the implementation of village rights and obligations.

All activities which include:

a. Planning

b. Implementation

c. Administration

d. Reporting

e. Village financial accountability

2. What is the legal basis for village financial management?

The principle:
a. Transparent
b. Accountable
c. Participative
d. Budget order and discipline

3. How long will the village financial management be?

One fiscal year from January 1 to December 31 of the current year.

4. Where is the Village Government's annual financial plan contained?

Set forth in the Village Revenue and Expenditure Budget (APBDesa)

5. Principles of Using Village Funds

Principles of Village Fund Users:

a. Justice

b. Priority Needs

c. Village Authority

d. Participative

e. Self-management and Village Resource Based

f. Village Typology

\begin{tabular}{|l|l|}
\hline \multicolumn{1}{|c|}{ PRINCIPLE } & \multicolumn{1}{|c|}{ DESCRIPTION } \\
\hline Justice & $\begin{array}{l}\text { Prioritizing the rights and interests of all villagers without } \\
\text { discrimination }\end{array}$ \\
\hline Priority needs & $\begin{array}{l}\text { Prioritizing the more urgent interests of the Village, more needed and } \\
\text { directly related to the interests of the majority of the Village } \\
\text { community }\end{array}$ \\
\hline Village Authority & $\begin{array}{l}\text { Prioritizing authority on origin rights and local authority at the village } \\
\text { scale }\end{array}$ \\
\hline Participative & Prioritizing community initiative and creativity \\
\hline $\begin{array}{l}\text { Self-management } \\
\text { and based on Village } \\
\text { resources }\end{array}$ & $\begin{array}{l}\text { Prioritizing independent implementation with the utilization of } \\
\text { Village natural resources, prioritizing the energy, thoughts and skills } \\
\text { of Village residents and local wisdom }\end{array}$ \\
\hline
\end{tabular}




\begin{tabular}{|l|l|}
\hline Village Typology & $\begin{array}{l}\text { Taking into account the circumstances and realities of the typical } \\
\text { geographical, sociological, anthropological, economic and ecological } \\
\text { characteristics of the Village, as well as changes or developments and } \\
\text { progress of the Village. }\end{array}$ \\
\hline
\end{tabular}

6. Priority for the Use of Village Funds

What are the priorities for using the 2018 Village Fund?
According to Permendes Number 19 of 2017, the priority is to:

a. Village development, and

b. Village community empowerment

\begin{tabular}{|c|c|}
\hline $\begin{array}{c}\text { VILLAGE } \\
\text { DEVELOPMENT FIELD }\end{array}$ & VILLAGE COMMUNITY EMPOWERMENT \\
\hline $\begin{array}{l}\text { Directed for the procurement, } \\
\text { construction, construction, } \\
\text { development and maintenance } \\
\text { of facilities and infrastructure: } \\
\text { a. Village; } \\
\text { b. Basic social services; } \\
\text { c. Village economic } \\
\text { enterprises; } \\
\text { d. Living environment; } \\
\text { e. And others }\end{array}$ & $\begin{array}{l}\text { Geared for: } \\
\text { a. Increase community participation in planning, } \\
\text { implementation and supervision of Village } \\
\text { development; } \\
\text { b. Capacity building and resilience of Village } \\
\text { communities; } \\
\text { c. Village information system development; } \\
\text { d. Support for the management of basic social service } \\
\text { activities; } \\
\text { e. Capital Support and management of productive } \\
\text { economic businesses; } \\
\text { f. Support for economic business management; } \\
\text { g. Support for environmental conservation management; } \\
\text { h. Development of inter-village cooperation and Village } \\
\text { cooperation with third parties; } \\
\text { i. Support to face and manage natural disasters and other } \\
\text { outbreaks; } \\
\text { j. Other areas of activity. }\end{array}$ \\
\hline
\end{tabular}

7. Constraints in Distribution and Use

What are the obstacles in distributing funds for the use of the Village Fund?

There are still obstacles in: a. Distribution, either from RKUN to RKUD or from RKUD to RKDes

b. Use, there are still uses of Village Funds that are not in accordance with the provisions

\begin{tabular}{|c|c|c|}
\hline \multicolumn{1}{|c|}{ Distribution Constraints } & \multicolumn{3}{|c|}{ Usage Constraints } \\
\hline \multicolumn{1}{|c|}{ From RKUN To RKUD } & 1. & Use outside the priority area \\
\hline $\begin{array}{l}\text { a. } \\
\text { Perkada counting procedures do not } \\
\text { comply with the provisions }\end{array}$ & 8. & $\begin{array}{l}\text { Expenditures are not supported by } \\
\text { evidence }\end{array}$ \\
\hline b. $\begin{array}{l}\text { The realization report has not been } \\
\text { submitted }\end{array}$ & 9. & \multicolumn{1}{|l|}{ Work by third parties } \\
\hline c. $\begin{array}{l}\text { Submission of phase II distribution in } \\
\text { the last month }\end{array}$ & 10. & $\begin{array}{l}\text { Tax does not comply with the } \\
\text { provisions }\end{array}$ \\
\hline
\end{tabular}




\begin{tabular}{|c|c|}
\hline RKUD TO RKD & $\begin{array}{l}\text { The village is not familiar with the } \\
\text { supply money mechanism }\end{array}$ \\
\hline $\begin{array}{l}\text { a. APBDes has not been / is late being } \\
\text { determined }\end{array}$ & Shopping outside of budget \\
\hline $\begin{array}{l}\text { b. Regulatory changes } \\
\text { c. Planning documents \& usage reports } \\
\text { do not yet exist }\end{array}$ & \\
\hline d. Change of Head of Village & \\
\hline EFFORTS ARE MADE & EFFORTS ARE MADE \\
\hline $\begin{array}{l}\text { a. Internal coordination of the Ministry } \\
\text { of Finance to accelerate the } \\
\text { distribution of Village Funds }\end{array}$ & $\begin{array}{l}\text { a.Bimtek \& training for local government } \\
\text { officials \& village officials }\end{array}$ \\
\hline $\begin{array}{l}\text { b. Bimetek and training for Regional } \\
\text { Government officials and Village } \\
\text { Officials }\end{array}$ & $\begin{array}{l}\text { b.socialization of priorities for the use of } \\
\text { Village Funds }\end{array}$ \\
\hline $\begin{array}{l}\text { c. Monitoring and evaluation of the } \\
\text { formulation of the regional head on } \\
\text { allocating DD per village and } \\
\text { distribution of DD }\end{array}$ & $\begin{array}{l}\text { c. Dissemination of Village Fund } \\
\text { Management. }\end{array}$ \\
\hline
\end{tabular}

8. Village income is all money received through a village account which is the right of the village in one fiscal year which does not need to be paid back by the village
Village income consists of:

1. Village Original Income (PADes)

2. Transfer

3. Other income

\begin{tabular}{|c|c|c|}
\hline \multicolumn{3}{|c|}{ VILLAGE REVENUE } \\
\hline $\begin{array}{l}\text { ORIGINAL VILLAGE } \\
\text { REVENUE (PADes) }\end{array}$ & TRANSFER & OTHER INCOME \\
\hline $\begin{array}{l}\text { a. Company results; } \\
\text { b. Asset yield; } \\
\text { c. Self-help, participation } \\
\text { and mutual cooperation; } \\
\text { and } \\
\text { d. Other original village } \\
\text { income }\end{array}$ & $\begin{array}{l}\text { a. Village funds; } \\
\text { b. Part of the proceeds from } \\
\text { regional taxes and levies of } \\
\text { regencies / cities; } \\
\text { c. Village Fund Allocation } \\
\text { (ADD); } \\
\text { d. Financial assistance from the } \\
\text { Provincial APBD; and } \\
\text { e. District / City APBD } \\
\text { Financial Assistance }\end{array}$ & $\begin{array}{l}\text { a. Non-Binding Third Party } \\
\text { Grants And Donations; } \\
\text { And } \\
\text { b. Others Legitimate Village } \\
\text { Income, (eg income from } \\
\text { cooperation with third } \\
\text { parties). }\end{array}$ \\
\hline
\end{tabular}

\begin{tabular}{|l|l|}
\hline COMPANY RESULTS & $\begin{array}{c}\text { SELF-SUPPORTING, PARTICIPATION AND } \\
\text { MUTUAL ASSISTANCE }\end{array}$ \\
\hline$-\quad \begin{array}{l}\text { Village BUM results, } \\
-\quad \begin{array}{l}\text { Ground the village } \\
\text { treasury }\end{array}\end{array}$ & \begin{tabular}{l} 
- $\begin{array}{c}\text { Build with your own strength that involves community } \\
\text { participation in the form of energy, goods that are } \\
\text { valued in money }\end{array}$ \\
\hline ASSET RESULTS
\end{tabular} \\
\hline
\end{tabular}




\begin{tabular}{|c|c|}
\hline $\begin{array}{ll}\text { - } & \text { Boat moorings, } \\
\text { - } & \text { Market Village, } \\
\text { - } & \text { Public baths, } \\
\text { - } & \text { Irrigation network }\end{array}$ & Results of village fees \\
\hline
\end{tabular}

In managing the Village Fund, the role of Village Head is the power of village financial management and represents the Village Government in ownership of separated village property.

The village head has the following powers:

c. Establish policies for implementing APBDesa

d. Determine the Village Financial Management Technical Implementer (PTPKD);

e. Determine officers who collect village revenues;

f. Approve the expenditures stipulated in the APBDesa; and

g. Take actions that result in spending at the expense of the Village Budget

h. The difference between Village Funds and Village Fund Allocation lies in the source of the funds

i. Village Funds come from the State Budget (APBN) while Village Fund Allocation comes from Local Goverment Budget (APBD).

9. What is the role of the Village Secretary in managing village finances?

The Village Secretary acts as the coordinator for the implementation of village financial management.

10. What are the duties of the Village Secretary as the village financial management coordinator?

The Village Secretary is in charge of:

a. Prepare and implement APBDesa

b. Prepare the Raperdes APBDesa

c. Compile APBDesa changes and APBDesa accountability;

d. Controlling the implementation of APBDesa activities;

e. Compile APBDesa reporting and accountability; and

f. Verify proof of receipt and issuance of APBDesa

11. What is the role of the section head in village financial management?
The section head has the following duties:

a. Prepare an activity plan;

b. Carry out activities and / or together with Village Community Institutions;

c. Carry out expenditure actions that burden the budget;

d. Control and report the implementation of activities to the Village Head; and

e. Prepare budget documents for the implementation of activities.

12. Who acts as treasurer in village financial management?

The treasurer is a staff element of the village secretariat in charge of financial administration to administer village finances.

13. Community Quality Improvement

A village government that has knowledge, experience and motivation and always collaborates in managing village funds with the community, directly and indirectly, it has improved the quality of life of the community to be prosperous and reduced poverty and increased job opportunities. This is indicated by:

1) Fulfilling basic needs such as food and nutrition, clothing, shelter, education and health (Basic Need Deprivation);

2) Conduct productive business activities,

3) Reaching access to social and economic resources;

4) Determining their own destiny and constantly getting discriminatory treatment, having feelings of fear and desire as well as apathy and fatalism;

5) Free yourself from mentally and culturally poor and always feel you have low dignity and self-respect (no freedom for poor).

\section{Conclusion}

1) The people of Oesao, Oebelo, Mata Air and East Baumata villages face many problems 
including lack of water, foodstuffs due to drought, many children who are affected by malnutrition and stunting, and unemployment.

2) Design a new approach that engages all stakeholders, leveraging their competence and creativity to design new solutions, as a dynamic 'living laboratory', the community offers the perfect platform for innovation with the use of the Village Fund.

3) The low level of education means that there are still several obstacles, especially in the management of village finances.

For suggestions, The development of the quality of Human Resources is increasingly important. This is because villages that employ Human Resources, want good results and benefits and can keep up with changes and developments that occur in the Village. Motivation and work experience are things that play an important role in increasing work effectiveness. Because people who have higher education, high motivation and work experience will try their best so that their work can succeed as well as possible, will form an increase in work productivity.

\section{Limitation and study forward}

This research was only conducted in the village survey of several villages located in the poverty line in Kupang Regency that is Oesao Village, Oebelo, Mata Air and East Baumata Village. For further research, it is expected to use other indicators that are not used in this study and to increase the number of research samples, in order to obtain more in depth results.

\section{References}

[1] Adisasmita, Rahardjo. (2013). Pembangunan Perdesaan: Pendekatan Partisipatif, Tipologi, Strategi, Konsep Desa Pusat Pertumbuhan. Yogyakarta, Graha Ilmu.

[2] Ana Pilar Pi Puig (2018). Reflecting on local reality: Tensions and challenges of sustainable development incontexts of urban poverty. Univers idad Nacional de La Plata (Argentina) ISSN2283-7949
Glocalism: Journal Of Culture, Politics And Innovation 2018,3, DOI: 10.12893/gjcpi.2018.3.5 Published on line by "Globuset Locus"at www. Glocalismjournal.net

[3] Daniel Gebretsadik Ayele (2019). Challenges to Rural Livelihoods: A Case Study of Chichu, Gedeo, Southern Ethiopia. The Journal Of Rural And Community Development, 14(2), 107-Xx ISSN: 1712-8277 (c) Journal Of Rural And Community Development.Www.Jrcd.Ca

[4] Faizatul Karimah, Choirul Saleh, Ike Wanusmawatie (2018). Pengelolaan Alokasi Dana Desa Dalam Pemberdayaan Masyarakat (Studi pada Desa Deket Kulon Kecamatan Deket Kabupaten Lamongan). Jurnal Administrasi Publik (JAP), Vol. 2, No. 4, Hal. 597-602|

[5] Fanggidae Apriana (2018). Tourism Development Model Using OVOP (One Village One Product) in Sabu Raijua Regency). Internasitional Journal of Business Accounting and Management. ISSN 2527-3531, Vol 3, Issue 1 dan 2 March-April 2018. www.doarj.org

[6] Hamam Serag El Din, etc (2016). Principles of urban quality of life for a neighborhood Author links open overlay panel.

https://doi.org/10.1016/j.hbrcj.2013.02.007

[7] Sugiyono (2008). Metode Penelitian Kuantitatif Kualitatif. Bandung Alfabeta.

[8] Murdiansyah, Isnan, Evaluasi Program Pengentasan Kemiskinan Berbasis Pemberdayaan Masyrakat, Studi Kasus Pada Program Gerdu-Taskin di Kabupaten Malang. WIGA Vol. 4 No. 1, Maret 2014 ISSN NO 2088-094493.

[9] Rosalie, etc, (2019). A quality of life questionnaire for adolescents with cerebral palsy: psychometric properties of the Bengali CPQoL-teens. Health and Quality of Life Outcomes volume 17, Article number: 135 
https://hqlo.biomedcentral.com/articles?ta

$\mathrm{b}=$ keyword

[10] Sayuti, Muh (2011). Pelembagaan Badan Usaha Milik Desa (BUMDs) Sebagai Penggerak Ekonomi Desa Dalam Upaya Penegentasan Kemiskinan Di Kabupaten Donggala, Academica Fisip Untad VOL.03 No. 02 Oktober 2011.

[11] Stiglitz, Sen \& Fitoussi (2009). The Measurement Of Economic Performance And Social Progress Revisited Ofcen ${ }^{\circ} 2009$ 33 December 2009.

[12] Deputi Bidang Pengawasan Penyelenggaraan Keuangan Daerah, 2015.

[13] Kementerian Keuangan Republik Indonesia, 2017.

[14] Peraturan Menteri No. 16 Tahun 2018.

[15] UU Nomor 6 Tahun 2014.

[16] Badan Pusat Statistik Provinsi NTT, 2019

[17] Pos Kupang 20/5/2019 dan 15/7/2019 